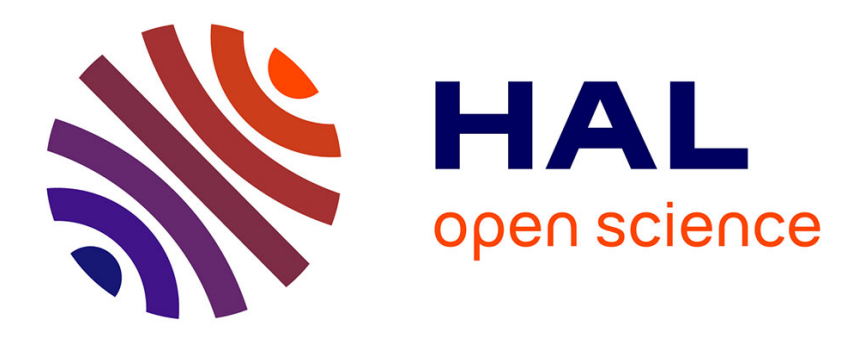

\title{
Phonological overgeneration in Paninian system
}

Malhar Kulkarni

\section{To cite this version:}

Malhar Kulkarni. Phonological overgeneration in Paninian system. First International Sanskrit Computational Linguistics Symposium, INRIA Paris-Rocquencourt, Oct 2007, Rocquencourt, France. inria-00207929

\section{HAL Id: inria-00207929 \\ https://hal.inria.fr/inria-00207929}

Submitted on 18 Jan 2008

HAL is a multi-disciplinary open access archive for the deposit and dissemination of scientific research documents, whether they are published or not. The documents may come from teaching and research institutions in France or abroad, or from public or private research centers.
L'archive ouverte pluridisciplinaire HAL, est destinée au dépôt et à la diffusion de documents scientifiques de niveau recherche, publiés ou non, émanant des établissements d'enseignement et de recherche français ou étrangers, des laboratoires publics ou privés. 


\title{
PHONOLOGICAL OVERGENERATION IN PANINIAN SYSTEM
}

\author{
Malhar Kulkarni \\ IIT, Powai, Mumbai- 400076 \\ and \\ M.M.Vasudevashastri Abhyankarashastri Pathashala, Pune. \\ malharditb.ac.in
}

\begin{abstract}
In this paper an attempt is made to study the problem of overgeneration that is caused by the application of the system of Pạnini The system of Pạnini is made up of certain rules stated by him and his commentators namely, Kätyāyana and Patañjali. These rules are supposed to produce the forms that are used in the language, i.e. Sanskrit. However, sometimes the technical application of these rules produces such forms which are not actually used in the language. In fact, sometimes it is beyond human capacities to use such forms. In the present paper two such cases dealing with the phonological overgeneration are studied and possible solutions are proposed to avoid the problem.
\end{abstract}

\section{INTRODUCTION:}

It has been demonstrated by Kiparsky and Staal(1988) how Paninian system functions on four levels, namely, semantic, deep structure, surface and phonological. This system however sometimes over-generates in perhaps, some of these levels. Of course Pannini (P) has no doubt laid down certain constraints with the help of which the system produces supposedly un-overgenerated forms. Prince and Smolensky (2002), have devoted a section on Panini's theorem of constraint ranking (5.3) Of course our judgement regarding the over-generativeness of a rule in the Asțādhy $\bar{a} y \bar{\imath}(\mathrm{A})$, it must be admitted here, is based entirely upon whatever evidance in the form of pre-paninian literature available to us.

\section{PHONOLOGICAL OVER-GENERATION}

This paper is devoted to phonological over-generation that still happens with all the possible constraints applying. There are two aspects that are studied in this paper,

(1) Nasalization and (2) Phonetic doubling

\subsection{Nasalization:}

8.4.45 states that yar ${ }^{1}$ occurring at the end of a pada, is optionally, (preferably, according to Kiparsky1980:1) substituted by the nasal, if a nasal follows.

(1)

$$
\begin{aligned}
& \text { etad murārih } \\
& =\text { etan murārih } \quad \text { / etad murārịh } \quad \ldots \quad 8.4 .45
\end{aligned}
$$

$\operatorname{Ka} t y a \bar{y} a n a(\mathrm{~K})$ has added a $\operatorname{Varrttika}(\mathrm{V})$ on this rule, to the effect that this nasalization takes place permanently if the following nasal is a part of a suffix (2)

$$
\begin{aligned}
& \text { tad }+ \text { maya } \\
& =\text { tan-maya } \\
& =\text { tanmaya }
\end{aligned}
$$

\subsubsection{Enviornment for nasalization:}

However, if we look at the way $\mathrm{P}$ has stated this rule, we have to take into account following table which shows clearly all possible environments in which this rule should apply and the possible results in the form of substitution of a nasal consonant. The top row and the left column, in the table, show the possible environment. The bottom row shows the resultant nasal consonant in place of the consonant written in the same column in top row. Thus for

\footnotetext{
${ }^{1}$ These phonemes are- all the stops including the nasals, semi vowels $(y, r, l, v)$ and sibilants except $h$.
} 
instance,

$$
\begin{aligned}
& {[. . \mathrm{y}]+[\mathrm{n} . .] /[\mathrm{m} . .] / \quad \ldots \quad 8.4 .45+\mathrm{K} \text { 's V }} \\
& =[. . \mathrm{y} \#]+[\mathrm{n} . .] /[\mathrm{m} . .] /
\end{aligned}
$$

Table 1 shows that any consonant mentioned in the top row occuring at the end of a pada and followed by any of the nasal consonants mentioned in the left hand column, is substituted by the nasal consonant shown in the bottom row. \# mark is used to show the nasal feature in the bottom row. * shows that these substitutions are not attested in Sanskrit. The order of sounds followed by $\mathrm{P}$ in his pratyāhāra sūtras is maintained here.

There are certain sounds in this table which are directly not applicable for this operation as they never occur at the end of a pada in Sanskrit. Such sounds are- $\mathrm{y}, 1, i, \tilde{n}, j h, b h, g h, d h, d h, k h, p h, c h$. Some grammatical entries do end in some of these sounds and hence it can be argued that by applying operations related to 0 suffix, one can generate padas with these sounds at the end. However, this argument does not hold valid as in the case of these consonants, the other rules namely, 8.2.30, 8.2.39 etc. will substitute them with the other consonants.

Thus consider the following example-

\begin{tabular}{llll}
$\begin{array}{l}\text { (3) } \\
\text { gumph }\end{array}$ & & $\ldots$ & Dhātupātha 6.31 \\
gumph & + kvip & $\ldots$ & 3.2 .178 \\
gu ph & + kvip & $\ldots$ & 6.4 .24 \\
guph & +0 & $\ldots$ & 6.1 .67 \\
= guph & & & \\
\hline guph & + su & $\ldots$ & $4.1 .1,2$ \\
guph & +0 & $\ldots$ & 6.1 .68 \\
gub & & $\ldots$ & 8.2 .39 \\
gub/gup & & $\ldots$ & 8.4 .56 \\
= gub / gup & & &
\end{tabular}

In the same way, other consonants will be substituted.

\subsubsection{Overgenerated nasalization:}

Now the rule, applied to all the remaining consonants should also apply to the following example-

(4)

catur mukha

8.4 .45

catu n mukha

However, this resultant form is not acceptable in Sanskrit. This is clearly an over- eneration.

8.4.58 states the substitution of a nasal in place of an anusvära when followed by almost same consonants(called as yay by P) mentioned in the top row of
Table 1 above except the last three. The rule can be shown as-

$$
\begin{array}{ll}
{[\ldots \text { anusvāra }]} & +[\text { yay... }] \\
=[\ldots \text { nasal }] & +[\text { yay... }]
\end{array}
$$

Thus by applying this rule we get forms like kantha, aikita, gumphita etc. Consider however, the following example-

(5)

kundam rathena

kundam rathena $\quad \ldots \quad 8.3 .23$

kundan rathena $\quad \ldots \quad 8.4 .58$

The resultant form here is not acceptable in Sanskrit. This is again over-generation.

One may argue about redundancy being the feature of use of the pratyāharras in the metalangauge of However, the tradition has taken pains in creating a constraint to check such forms in the form of statements in this regard. $\mathrm{Pa}$ in the context of the above example says-

rephoṣmanām savarnā na santi ${ }^{2}$. (the sounds $r$ and the sibilants do not have any homogenious(nasal))

There are at least some constraints in the form of statements of the later commentators to check the overgeneration as shown above. However, in the case of phonetic doubling mentioned below, we see hardly any constraint to check the overgeneration.

\subsection{Phonetic doubling:}

$\mathrm{P}$ in his $\mathrm{A}$ has dealt with the process of reduplication at three places; (i) $6.1 .1-12^{3}$, (ii) $8.1 .1-15$, (iii) 8.4 .46 52. (i) deals with the reduplication of verbal roots in the forms of present as well as perfect tense and also in forming complex verbal roots such as desiderative and frequentative. In a nutshell, this reduplication applies to the aiga in Paninian terminology. (ii) deals with the reduplication of the entire pada. The last section in the A mentioned above, deals with the reduplication of the consonants. The paninian tradition has augmented the existing set of rules laid down by $\mathrm{P}$ in this section, in the form of Vārttikas (maily written by $\mathrm{K}$ ) in this regard and the later tradition has interpreted certain statements of Patañjali $(\mathrm{Pa})$ in such a manner that the resultant forms can only be termed as over-generated ones. The later paninian tradition has done this exercise at many places and has come up with such overgenerated

\footnotetext{
${ }^{2}$ VyākaraëaMahābhāṣya of Patañjali, 2001, Vol.1, p 130.

${ }^{3}$ More recently, Kiparsky in a forthcoming article available on his webpage, has discussed it.
} 
Table 1: Consonants and their substitutes according to 8.4.45

\begin{tabular}{|c|c|c|c|c|c|c|c|c|c|c|c|c|c|c|c|c|c|c|c|c|c|c|c|c|c|c|c|c|c|c|c|c|}
\hline & $\mathrm{y}$ & $\mathrm{v}$ & $\mathrm{r}$ & 1 & $\tilde{\mathrm{n}}$ & $\mathrm{m}$ & $\dot{\mathrm{n}}$ & $n$ & $\mathrm{n}$ & jh & bh & gh & ḍh & $\mathrm{dh}$ & $\mathrm{j}$ & $\mathrm{b}$ & $\mathrm{g}$ & $\stackrel{d}{d}$ & $\mathrm{~d}$ & $\mathrm{kh}$ & $\mathrm{ph}$ & ch & th & th & $\mathrm{c}$ & $t$ & $\mathrm{t}$ & $\mathrm{k}$ & $\mathrm{p}$ & ś & $\underline{s}$ & $\mathrm{~s}$ \\
\hline$\dot{\mathrm{n}}$ & & & & & & & & & & & & & & & & & & & & & & & & & & & & & & & & \\
\hline$\tilde{n}$ & & & & & & & & & & & & & & & & & & & & & & & & & & & & & & & & \\
\hline n & & & & & & & & & & & & & & & & & & & & & & & & & & & & & & & & \\
\hline $\mathrm{n}$ & & & & & & & & & & & & & & & & & & & & & & & & & & & & & & & & \\
\hline $\mathrm{m}$ & & & & & & & & & & & & & & & & & & & & & & & & & & & & & & & & \\
\hline & $\mathrm{y}$ & $\mathrm{v}$ & $\mathrm{n}$ & 1 & $\frac{\bar{n}}{\tilde{n}}$ & $\mathrm{~m}$ & $\dot{\mathrm{n}}$ & $\mathrm{n}$ & $n$ & ก̃ & $\mathrm{m}$ & $\dot{\mathrm{n}}$ & $\mathrm{n}$ & $\mathrm{n}$ & $\tilde{\mathrm{n}}$ & $\mathrm{m}$ & $\dot{\mathrm{n}}$ & $\mathrm{n}$ & $\mathrm{n}$ & $\dot{\mathrm{n}}$ & $\mathrm{m}$ & $\tilde{\mathrm{n}}$ & $\mathrm{n}$ & $\mathrm{n}$ & $\tilde{\mathbf{n}}$ & $\mathrm{n}$ & $\mathrm{n}$ & $\dot{\mathrm{n}}$ & $\mathrm{m}$ & $\tilde{\mathrm{n}}$ & $\mathrm{n}$ & $\mathrm{n}$ \\
\hline & $\#$ & $\#$ & $\dot{*}$ & \# & & & & & & & & & & & & & & & & & & & & & & & & & & $*$ & $\dot{*}$ & $*$ \\
\hline
\end{tabular}

Table 2: Enviornment for Phonetic doubling

\begin{tabular}{|l|l|l|l|l|}
\hline $\mathbf{1}$ & $\mathbf{2}$ & $\begin{array}{l}\text { 3 Consonant } \\
\text { Reduplicated }\end{array}$ & $\mathbf{4}$ & Rule of Panini \\
\hline vowel & $r / h$ & yar & - & 8.4 .46 \\
\hline- & vowel & yar & No vowel & 8.4 .47 \\
\hline vowel & Yan & may & - & $\begin{array}{l}\text { K \& Pat on } \\
8.4 .47\end{array}$ \\
\hline vowel & may & yan & - & As above \\
\hline- & $\hat{S}$ ar & khay & - & As above \\
\hline- & khay & $\hat{S}$ ar & - & As above \\
\hline
\end{tabular}

forms. The such extreme cases are presented in this paper and an attempt is made to study the approach of the Paninian system to handle this phenomenon.

(6) putrādin̄̄ tvam asi pāpe

(Oh! son-eater woman, shame on you!)

puttrādin̄̄ sarpin̄ī

(she-snake is son-eater. )

In this case, $\mathrm{t}$ is seen reduplicated alongwith the change in the meaning. This case is noted by 8.4.48.

\subsubsection{Enviornment for Phonetic doubling:}

In the same section, some other phonemes are also noted for their reduplicated occurrence. $\mathrm{K}$ and pat have also noted down this tendency in some other phonemes. These phonemes are- same mentioned in fn 2 . In table 2 they are referred to as yar, as used by P. In the table 2, these rules are explained with all details, namely environments- prior and posterior

Here 1, 2, 4 refer to the environment for phonetic doubling. The order indicates the positions of these environments and the position of the phoneme reduplicated. The examples for these two rows are-

(7) haryyanubhavah

(ha-r-y anubhavah $>$ phonetic doubling of $\mathrm{y}$ )

(8) (a) rāmātt

(rām $\bar{a}-t$-(no vowel) $>$ phonetic doubling of $\mathrm{t}$ )

(b) sudhdhyupāsyah

(s-u-dh-y upasyah $>$ phonetic doubling of y).

\subsection{2. $K$ and $P a$ on the environment for phonetic doubling:}

While commenting upon 8.4.47, K notes- dvirvacane yano mayah. On this $\mathrm{Pa}$ has a two fold comment. He says-

\author{
dvirvacane yano maya iti vaktavyam. \\ Kim udāharanam yadi yana iti \\ pañcamī maya iti șașthi \\ ulkkā valmmikam ity udahāranam. Atha maya \\ iti pancamī yana iti șașthī \\ dadhyyatra madhvvatrety udāharanam
}

This means- In the rules dealing with the process of phonetic doubling, the words yano mayah should be stated. What is the example? If yanah (yan is $y, v, r$, $l$ ) is taken to be ablative and mayah (may is all stops except nasal palatal) is taken to be genitive, then the examples are -

(9) ulk $\underline{\boldsymbol{k}} \bar{a} /$ valmmikam

and if mayah is taken to be ablative and yanah is taken to be genitive, then the examples are-

(10)dadhyyatra / madhvvatra.

Same argument is applied to another statement of $\mathrm{K}$, namely śa $\operatorname{san} k$ haya ${ }^{4}$ which provides us with the following examples-

(11) sththā $\bar{l} \bar{l} /$ sthth $\bar{a} t \bar{a}$

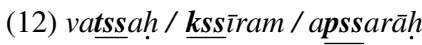

This way of interpreting the statements of $\mathrm{K}$ on the rules of $\mathrm{P}$ becomes a peculiar feature of the system of paninian grammar. Later tradition of paninian grammar thus by interpreting statements of $\mathrm{K}$ and $\mathrm{Pa}$ and

\footnotetext{
${ }^{4}$ This statement means that khay is reduplicated if it occurs after śar and śar is reduplicated if it occurs after khay. śar stands for all the sibilants except $\mathrm{h}$ and khay stands for all the voiceless stops.
} 
$\mathrm{P}$ have noted down forms which we here address as overgenerated forms.

We note that this feature is also noted by nonpaninian systems such as Kätantra. A commentary on PrakriyāKaumudī namely Prakāś a notes that according to Kätantra school the phonetic doubling in a particular case will give rise to only 32 forms and not more ${ }^{5}$.

\subsubsection{Twice Occurences of same consonant in San- skrit}

It is noteworthy to study the structure of the consonant cluster in Sanskrit. A list of such clusters is available in Coulson Michael, 2003, p 22-24. We concentrate on a cluster of two consonant of same phonetic value. In other words, we concentrate on the twice occurrence of the same consonant. In the table 3 , a list of such consonant clusters is provided. Table 3 shows us the consonants which can have twice occurrence without applying the rules of phonetic doubling.

Table 3: Twice occurences of same consonant

\begin{tabular}{|l|l|}
\hline$k$ & $\begin{array}{l}\text { (i)Final }+ \text { initial of the next word } \\
\text { (ii)Prefinal }\end{array}$ \\
\hline$g$ & Final + initial of the next word \\
\hline$c$ & Final + initial of the next word \\
\hline$j$ & Final + initial of the next word \\
\hline$t$ & Final + initial of the next word \\
\hline$d$ & Final + initial of the next word \\
\hline$p$ & Final + initial of the next word \\
\hline$b$ & Final + initial of the next word \\
\hline $\mathrm{n}$ & Final + initial of the next word \\
\hline$n$ & $\begin{array}{l}\text { (i) Final }+ \text { initial of the next word } \\
\text { (ii)Pre-final }\end{array}$ \\
\hline $\mathrm{n}$ & Final + initial of the next word \\
\hline$m$ & Final + initial of the next word \\
\hline s & Final + initial of the next word \\
\hline$s$ & Final + initial of the next word \\
\hline$s$ & Final + initial of the next word \\
\hline
\end{tabular}

A careful glance at table 3 will point out that all these consonants fall in the domain of the application of the phonetic doubling rules mentioned above in Table 2. Therefore, if the rule for phonetic doubling is applied to these already existing two consonants, we get three same consonants occurring one after another. Such a form is noted to exist optionally by $\mathrm{P}$ in the case of consonants except nasals by the 8.4.65.

\footnotetext{
${ }^{5}$ PrakriyāKaumudī, 2000, Vol.I, p 158.
}

\subsubsection{Generation of Phonetic doubling in later tra-} dition:

A $17^{\text {th }}$ century grammar text, VaiyākaranaSiddhāntaKaumudī (VSK) records following cases of phonetic doubling-

(13) rāmātt rāmāadd./ VSK 206, dvitve rūpacatuștayam. (in the forms $r \bar{a} m \bar{a} t$ and $r \bar{a} m \bar{a} d$, after applying the rules of phonetic doubling we get 4 forms).

(14) aidhidhvam / VSK 2258, dhadhayor vasya masya ca dvitvavikalpātșodașarūpāni. (by reduplicating $v$ and $m$ when immediately before $d h a$ and

(15)samskartā / VSK 138, anusvāravatām anusvārasyāpi dvitve dvādasa. (after reduplicating the anusvāra in the forms already containing it, we get 12 forms).

(16) $g a v a \bar{k} /$ VSK 443

Cases (15) and (16) deserve a special attention as they pose a problem.

\subsubsection{2.2.4.1 Generation of Phonetic doubling in the forms of samskartā}

(15) samskarta - This word is formed in the following way ${ }^{6}$ -

$$
\begin{array}{lll}
\text { sam }+ \text { kartā } & & \\
\text { sam }+ \text { s- kartā } & \ldots & 6.1 .134 \\
\text { sar }+ \text { s-kartā } & \ldots & 8.3 .5 \\
\text { saṃr }+ \text { s-kartā } & \ldots & 8.3 .2 / 8.3 .4 \\
\text { saṃs }+ \text { s-kartā } & \ldots & 8.3 .15
\end{array}
$$

Along with this form there is an optional form that is available in which in place of $m$ there occurs an anusvāra. In the following two tables (Table 4 and Table 5), forms with $m$ and anusvāra are presented.

In Table 4 and 5, we see phonetic doublings of $s$, $t, k$ and more problematically of the anusvarra. This phonetic doubling of anusvara is based on the argument of $\mathrm{K}$ that ayogavāha ${ }^{7} \mathrm{~s}$ are to be included in the pratyāhāra at as well as sar by the statementayogavāhānam aț̦unatvam śarșu jaś tvașatve.

\footnotetext{
${ }^{6}$ I have to turn to Devnagari fonts for these two case to stress the amount of problem.

${ }^{7}$ The term ayogavāha refers to anusvāra, visarga, jihvāmulīya and upadhmānīya, Vy $\backslash=$ akaraëaMahābhāṣya of Patañjali, 2001, Vol.1, p 132
} 
Table 4: Forms of samskartā with a first nasal vowel

\begin{tabular}{|c|c|}
\hline Forms & Explanation \\
\hline संस्कतां & Deletion of first $s$ - comment of Pa-samo \\
\hline सेस्स्क्तां & va lopam ity ehe Mbh. on P.8.3.5 \\
\hline संस्स्स्कतां & Phonetic doubling of $1^{\text {st }} s$ by P 8.4 .47 \\
\hline 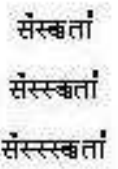 & $\begin{array}{l}\text { Phonetic doubling of } k \text {-sar ah hhayath } \\
\text { referred to in Table } 2 \text { above. }\end{array}$ \\
\hline
\end{tabular}

\section{Forms संस्कत्तां संस्सक्त्रां संस्स्क्कत्तां

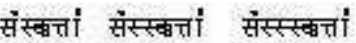

Phonetic doubling of $t$ in all the above 6

forms by dvirvacane yano mayah.

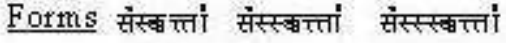 \\ $2^{\text {rd }}$ Phonetic doubling of $t$ in the first 6 \\ forms by dvirvacane yano mayath

\begin{tabular}{|c|c|c|c|}
\hline \multirow{6}{*}{ Forms } & संस्कताँ & संस्सक्कताँ & संस्स्स्कता \\
\hline & संस्क्त्तां & संस्स्बत्बताँ & संस्सस्क्रताँ \\
\hline & संस्कत्तां & संस्सकत्त्तां & संस्स्स्कत्ताँ \\
\hline & संस्ब्त्त्ताँ & संस्स्त्बत्ताँ & संस्स्स्र्ध्त्ताँ \\
\hline & संस्कत्त्ताँ & सैस्स्कत्त्त्तां & सैस्स्स्क्त्त्ताँ \\
\hline & संस्त्व त्तार्ता & संस्स्बक्त्त्तां & संस्स्स्त्र त्त्तां \\
\hline
\end{tabular}

N asalization of the final vowel by 8.4 .57 in

all the 12 form s mentioned above. In all,

we have 24 forms in this row.

\subsubsection{2.2.4.2 Generation of Phonetic doubling in} the forms of Gavāk

The Paninian Dhātupātha notes that the root añc is used in two senses viz. gati(to go) and püjana(to worship/ respect). In the sense of 'one who goes to a cow' and in the sense of 'one who worships a cow', the derivations that take place according to the rules of A are shown in the table 6 and table 7 respectively.

In the above tables, the underlined forms are the forms of a noun derived from a verbal root. Note that the difference in the forms in these tables is a mere $n$ which
Table 6: Derivation of Gavāk (one who goes to a cow)

$\begin{array}{llll}\text { go } & +a \tilde{n} c & \ldots & \text { (in the sense of to go ) } \\ \text { go } & +a \tilde{n} c+k v i n & \ldots & \text { A. } 3.2 .59 \\ \text { go } & +a c & \ldots & \text { A } 6.4 .24, \text { A.6.1.67 } \\ \text { goc } & \text { /go } a c & \ldots & \text { A } 6.1 .123 \\ \text { goc } & \text { /gavāc/goac } & \ldots & \text { A.6.1.109,122,123, }\end{array}$

Table 7: Derivation of Gavāanc (one who worships a cow)

\begin{tabular}{|c|c|c|c|}
\hline go & $+a \tilde{n} c$ & $\cdots$ & (in the sense of to go ) \\
\hline go & $+a \tilde{n} c+k v i n$ & $\ldots$ & A. 3.2 .59 \\
\hline go & $+a \tilde{n} c$ & & A 6.1 .67 \\
\hline gonc & I gava añc & $\ldots$ & A 6.1 .123 \\
\hline goñc & / gavāanc / go añc & $\ldots$ & A.6.1.109,122,123, \\
\hline
\end{tabular}

has brought about a sea of change in the meaning as well as the form itself. That is why P has noted them with all their variations.

When we take these 6 forms as the base and start adding the sup terminations, we get tables 8 and 9 for these two tables. Tables 8 and 9 correspond to Tables 6 and 7 mentioned above. These are the forms in neuter gender. There are certain specific processes for neuter forms. That is why they are selected here. In these tables, in each slot, there are many optional forms shown. They result out of the optional application of the rules namely, 6.1.109, 6.1.122 and 6.1.123.

The final square in Table 9 has got 9 forms. The last 3 forms are a result of the application of the statement of $\mathrm{K}^{8}$ according to which the $1^{\text {st }}$ class consonant is replaced by the $2^{\text {nd }}$ class consonant of the same class. Thus we see here $k$ is replaced by $k h$. These are the forms, we can say on the authority of A and K, which are actually spoken by people. So far there is no problem. When we apply the rules of phonetic doubling of certain consonants to these abovementioned Table 8 and 9 , we start facing a problem.

\subsubsection{Effects of phonetic doubling on forms in} Tables 8 and 9:

In Table 10 and 11 (as shown in the appendix), the reduplicated forms of the forms mentioned in Table 8 and 9 respectively are presented.

In the table 10 (as shown in Appendix), we note that the phonetic doubling of $k, g, \tilde{n}, y, m$ has increased the number of forms (which are indicated in each square).

\footnotetext{
${ }^{8}$ cayo dvitīyā śari pauskarasādeh / on 8.4.48
} 
The reasoning for the phonetic doubling of $k, g, \tilde{n}$ is 8.4.47. The reasoning for the phonetic doubling of $y$ and $m$ is the same as mentioned in Table 5 namely, dvirvacane yano mayah. We also note that there is a phonetic doubling of even a visarga in certain forms. The reasoning for this phonetic doubling is same as mentioned after Table 5, namely, inclusion of visarga in the pratyāhāra yar. Also there is nasalization which is marked by a sign on certain forms which has added those many forms.

We note that in the table 11 (as shown in the Appendix) the following consonants apart from the ones mentioned in Table 7 are reduplicated- $i, s$. The reasoning for phonetic doubling of $i$ is 8.4.47 and for $s$ is the one mentioned in Table 4. namely, ś arah khayah. We also note that in some forms even the visarga is reduplicated like in the previous table. In Table 10 and 11 (as shown in the Appendix), we also note that in some forms three consonants are simultaneously reduplicated. We also see that nasalization is marked with the sign in some forms.

Thus if we compare the tables 10 and 11 (as shown in the Appendix) statistically we come up with the following picture-

\begin{tabular}{|c|c|}
\hline Unduplicated & Duplicated + Nasalized \\
\hline 49 (Table 8$)$ & 196 (Appendix: Table 10) \\
\hline 69 (Table 9) & 267 (Appendix: Table 11) \\
\hline
\end{tabular}

If we are adopting the Paninian framework for generating forms by machine we will face similar problems if we apply the rules of phonetic doubling .

\section{PROPOSED SOLUTION :}

This overgeneration of forms is caused by-

(i) redundency of the pratyāhāra.

(ii) application of the rules of phonetic doubling mechanically.

(iii) application of statements and interpretations of later paninian commentators.

To solve this problem we propose the following:

If we are going to apply the rules of phonetic doubling we must make a rule that -

R1 The visarga should never be reduplicated.
R2 An anusvara should never be reduplicated.

R3 The rule of phonetic doubling should not be applied more than once to one consonant.

R4 The rule of phonetic doubling should not be applied to more than one consonant simultaniously.

In order to remove the redundency, we have to rely upon the statements of the later comentators and take note of their statements and modify the rule accordingly.

\section{ACKNOWLEDGEMENT}

I wish to express gratitude to my students Ms.A.Ajotikar, Ms.T.Aajotikar and Ms.Sarnaik, at the Abhyankarashastri Pathashala, Pune for helping me type out the forms in tables presented in this paper. I also wish to express my gratitude to all the scholars who made suggestions and remarks which helped improve this article immensely. I wish to thank Prof. Kiparsky for providing me with the details of the reference of one of his forthcoming publications. I wish to thank also my student Ms. Chatali Dangarikar for helping me format the text of this article.

\section{REFERENCES}

K. V. Abhyankar, editor. 1943. VyākaranaMahābhāṣya of Patañjali with Marathi Translation (7volumes). D.E.Society. reprint, Sanskrit Vidya Parisamstha, Pune, 2007.

Prof. Balshastri, editor. 2001. VyākaranaMahābhāsya of Patañjali, alongwith Pradīpa, Udyota and Śabdakaustubha,. Pratibha Prakashan, New Delhi. edited originally by Shri. GuruprasadShastri, reedited by Prof. Balshastri.

B.K.Dalai, editor. 2007. Phonology, in Studies in Sanskrit Linguistics,. Bharatiya kala Prakashan, New Delhi.

Otto Böhtlingk, editor. 1998. Pāninis Grammatik. Motilal Benarsidass, New DElhi, $1^{\text {st }}$ indian edition edition. Aș̣ādhyāȳī edited and translated into German. 
George Cardona and Dhanesh Jain, editors. 2003. Indo-Aryan Languages. Number 11 in Routledge Language Family Series. New Fetter Lane, London EC4P4EE.

George Cardona. 2004. Recent researches in Paninian studies. Motilal Benarsidas, , Delhi, 2nd revised edition edition.

Michael Coulson. 2003. Teach yourself Sanskrit. Hodder Headline Ltd., revised by prof.richard gombrich and dr james benson edition. 1st published in 1976.

Dr. GirijaKumar Dixit, editor. 1987. Paribhāśenduśekhara of Nāgeśa, alongwith the commentary Sarvamangala,. Sampurnananda Sanskrit University, varanasi edition.

Dr. Sitaramashastri, editor. 1996.

Bṛhacchabdenduśekhara of Nāgeśa (in 3 parts). Sampurnananda Sanskrit University, Varanasi, $1^{\text {st }}$ edition edition.

G.Caturveda and P.Bhaskar, editors. 1987. Vaiyākarana-Siddhānta-Kaumud̄̄, alongwith BālaManoramā and Tattvabodhin̄̄,. Motilal Benarsidass.

Paul Kiparsky and Staal J.F, 1988. Modern Studies in Sanskrit, chapter Syntactic and Semantic relations in Panini.

Paul Kiparsky. 1980. Panini as a variationist. Centre of Advanced Study in Sanskrit,University of Poona, in collaboration with MIT press, Cambridge(Massachusetts, U.S.A.) and London (England).

Paul Kiparsky. (forthcoming). Reduplication in stratal ot. Available at: http://www.stanford.edu/ kiparsky/Papers/reduplication.pdf.

Pt. Muralidhar Mishra, editor. 2000. Prakriyākaumudī with Prakāśa (in 3 parts). Sampurnanada Sanskrit University, Varanasi.

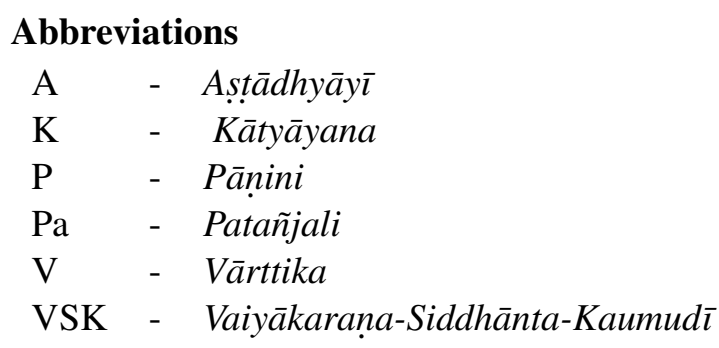


Appendix: Table 10:Phonetic doubling in the declension of Gavāc

\begin{tabular}{|c|c|c|c|}
\hline & 1 & 2 & 3 \\
\hline 1 & 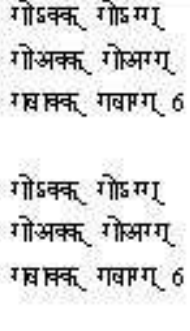 & $\begin{array}{l}\text { गोनी } \\
\text { गोची }\end{array}$ & 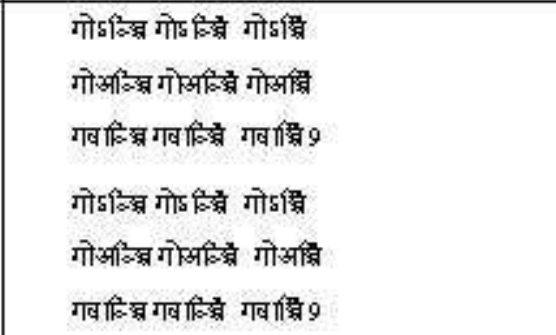 \\
\hline 3 & गोर्चो & 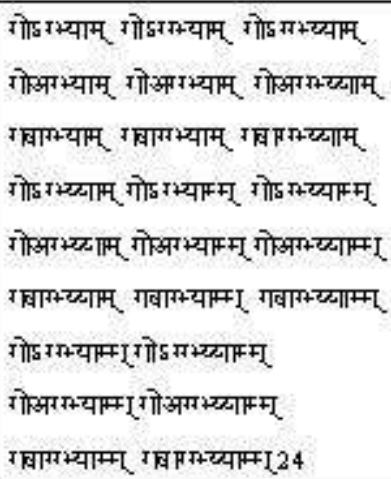 & 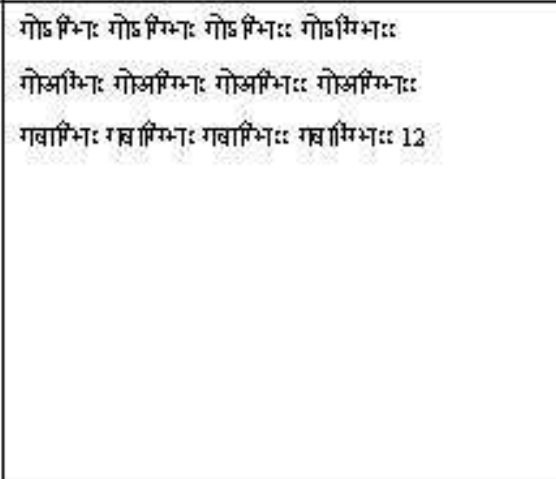 \\
\hline 4 & गोचे & Same as above 24 & 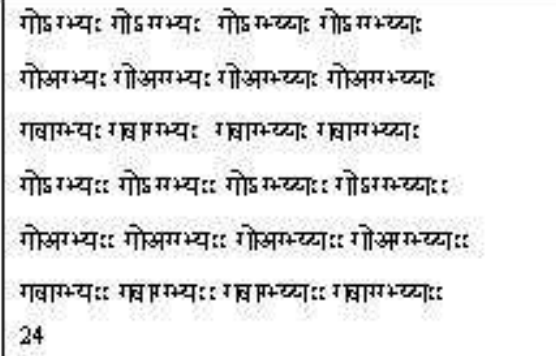 \\
\hline 5 & गोचः & Same as above (24) & Same as above 24 \\
\hline 6 & गोचः & गोचोह: & गोणाम्मा \\
\hline$?$ & गोरि & गोचोहः & 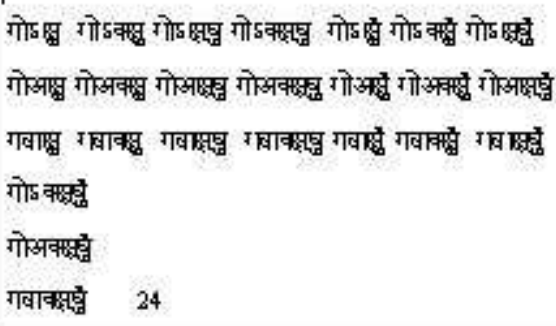 \\
\hline
\end{tabular}


Appendix: Table 11:Phonetic doubling in the declension of Gavā̃nc

\begin{tabular}{|c|c|c|c|}
\hline \multicolumn{4}{|c|}{ गोऽश्र् गोअश् गबाब्य पूलांधो द्वित्व } \\
\hline & $\begin{array}{l}\text { गोक्इ्ड } \\
\text { गोअह्इ } \\
\text { गबाइ्क् }\end{array}$ & 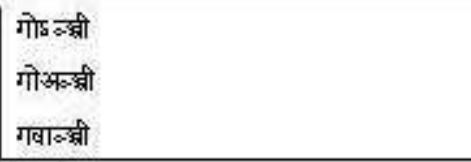 & 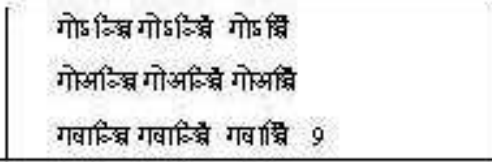 \\
\hline 2 & 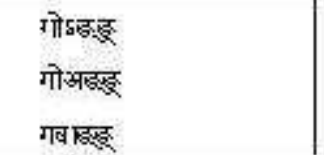 & $\begin{array}{l}\text { गोड ब्री } \\
\text { गोअन्द्री } \\
\text { गबान्द्री }\end{array}$ & 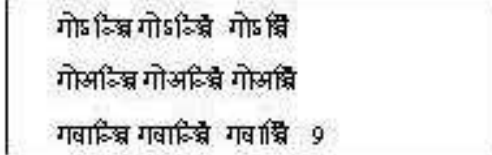 \\
\hline 3 & 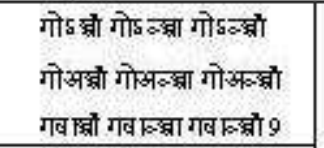 & 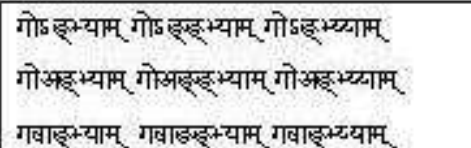 & 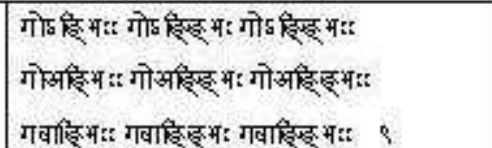 \\
\hline & 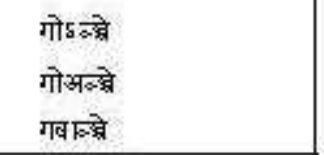 & 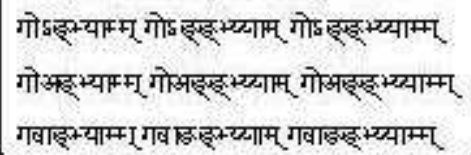 & 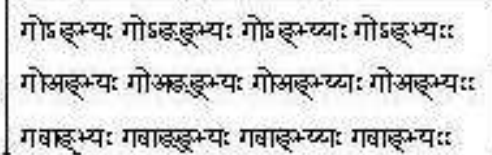 \\
\hline 5 & 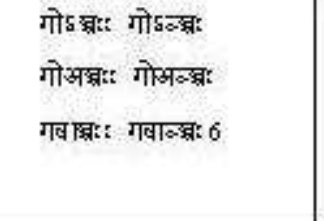 & 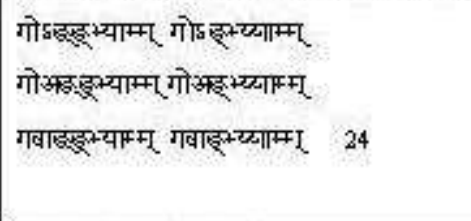 & 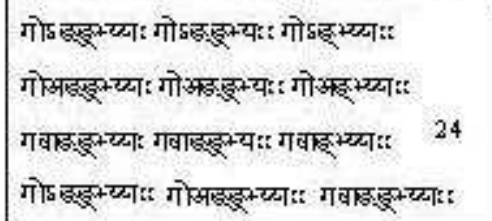 \\
\hline 6 & same as above 6 & 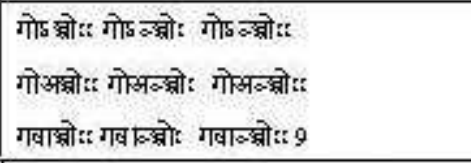 & 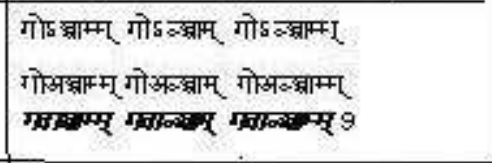 \\
\hline$?$ & 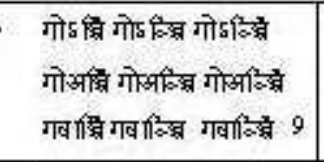 & 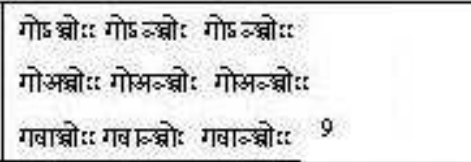 & 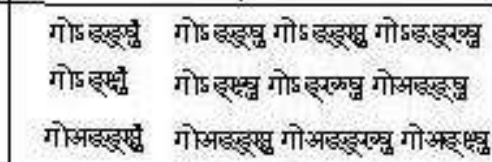 \\
\hline & 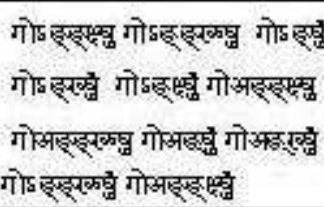 & 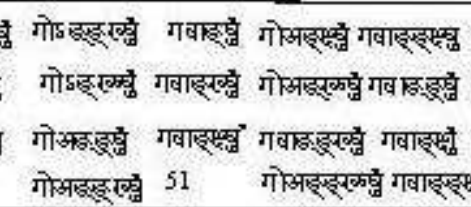 & 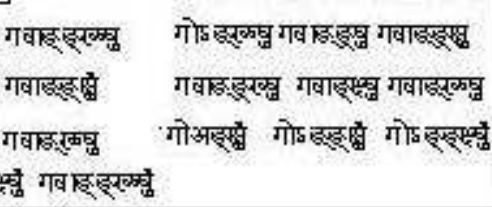 \\
\hline
\end{tabular}

